\title{
Manpower Planning in the Professions
}

\author{
DAVID STAGER* AND NOAH M.MELTZ**
}

\begin{abstract}
Manpower planning has been the subject of discussion and heated debate for more than a decade. Proponents have claimed that planning will enhance economic growth, particularly when it relates to professional and skilled manpower. ${ }^{1}$ Opponents have claimed that such planning distorts the market and will lead to excess supply or excess demand and in either case is costly in terms of economic resources. ${ }^{2}$

Our objective in this paper is to outline the general issues in manpower planning, briefly look at what is being done today in Canada, and then offer some suggestions concerning directions manpower planning might take. This paper is not intended to be a comprehensive review of the subject since other studies have gone into far more depth. ${ }^{3}$ Instead, we want to raise what we consider to be the major questions concerning how and what manpower planning is done.
\end{abstract}

\section{RESUME}

La planification de la main-d'oeuvre se fait un sujet de discussion et de débats animés depuis plus d'une décennie. Les défenseurs ont prétendu que la planification rehaussera la croissance économique, particulièrement en ce qui trait à la main d'oeuvre professionnelle et qualifiée. Les adversaires ont prétendu qu'une telle planification déforme le marché, aboutira à une offre excédentaire ou à une demande excédentaire et, dans les deux cas, s'avère coûteux en termes de ressources économiques.

L'objectif de la présente recherche est de tracer les questions générales en ce qui concerne la planification de la main-d'oeuvre. Cette étude ne prétend pas être une revue complète de la question. D'autres recherches l'approfondissent davantage. Au lieu de cela, nous voulons soulever ce que nous estimons les questions majeures: comment se fait la planification de la main-d'oeuvre? et de quoi s'agit-il?

* Department of Political Economy and Institute for Policy Analysis, University of Toronto.

** Department of Political Economy and Director, Centre for Industrial Relations, University of Toronto. 


\section{Some Preliminary Definitions}

There appears to be no generally accepted definition of "manpower planning". Perhaps it would be more accurate to say that there are both broad and narrow interpretations of this term. Both of these approaches tend to be concerned only with policies affecting the supply side of the labour markets, leaving the demand side to policies focussing on the level and conditions of employment or on welfare services. ${ }^{4}$ The wider view of manpower planning encompasses issues such as quality of training, in-service training and continuing education, competence testing, and the organizational characteristics of specific labour markets. The narrower view of manpower planning is concerned primarily with numbers; that is, with the number of persons available - or potentially available - to specific labour markets. In this paper we deal almost exclusively with this latter interpretation of manpower planning.

One should also draw the distinction between private and public manpower planning. Many employers, including some of the larger ones, pay little attention to explicit manpower planning, and particularly to continuous long-term planning. For those firms or organizations which do have an administrative division responsible for manpower, the emphasis tends to be on staffing needs in the near-term and on job descriptions, pay schedules, and on-the-job training. Public manpower planning necessarily takes a longer, broader view of labour supply.

\section{Objectives of Manpower Planning}

The basic objective in public manpower planning is to avoid or to minimize a shortage or surplus of specific types of labour at a given wage rate. This is usually the prevailing wage rate, although the objective may be to increase supply in order to lower the relative price in a specific labour market. This basic objective may be related to other public policy areas. Manpower planning is obviously a component of general economic planning: target growth rates and specific output goals require that the appropriate stock of manpower is available to meet these higher-order objectives. ${ }^{5}$ It is also necessary to coordinate manpower planning with other public concerns - immigration, regional development, science policy - to assure compatibility and consistency of such policies. Even if none of the preceding problems were present, a public manpower policy would be necessary to take account of what economists would call "positive externalities", namely the social benefits associated with particular occupations. By definition, these benefits are not taken into account in individuals' decision-making; hence there would be underinvestment in some areas of manpower development if these decisions were left to the private market.

Although we are taking as the objective of manpower planning that specific labour markets should be in equilibrium (quantity supplied equals quantity demanded at the prevailing wage), some persons would describe some situations as "shortages" or "surpluses" even when the markets were in equilibrum. As income differentials narrow - for example between professors and plumbers -- some professors might suggest that there is a shortage of plumbers simply because their relative incomes have changed. Similarly one hears of the "shortage" of cleaning-ladies as it becomes increasingly difficult to find domestic help at what was considered to be the traditional and proper relative wage. 
Another view of labour shortages or surpluses is based on rates of return to investment in education and training. It has been suggested that even though labour markets might be in equilibrium, a substantial and persistent difference in the rates of return to different occupations reveals imperfections in the operation of such labour markets which require correction through public manpower and other policies. ${ }^{6}$ Current rate of return estimates show physicians and dentists well ahead of lawyers and engineers, ${ }^{7}$ while the reverse was true in the early $1930 \mathrm{~s}^{8}$

Yet a third alternative view of the shortage/surplus question is that recurring short-run shortages and surpluses, however defined, are inevitable in any dynamic economy. ${ }^{9}$ There will be a "temporary shortage" in the very short run if demand increases quickly - particularly for occupations with longer training periods - but this should require no policy action. However, if demand is steadily increasing relative to supply, then we will face a "chronic shortage" due to the supply lag and public intervention will be required if a steady increase in the relative wage for that occupation is to be avoided. The danger in this situation is evident in the university teacher case: the demand for academics increased steadily through the 1960's, university salaries and subsidies for Ph.D. students were increased substantially, and then demand slackened while Ph.D. output continued at roughly the same rate. ${ }^{10}$

\section{Alternative Techniques in Manpower Forecasting}

While these latter two views of labour market imbalances have substantial merit, we are concerned here only with the "equilibrium at a given wage" approach because this is the most commonly assumed objective in manpower planning. This approach requires a forecast of the demand for specific kinds of labour services and a forecast of supply. Various forecasting methods used on the demand side can be grouped in three categories: 1) employer surveys; 2) ratios and trends; 3) econometric models.

The employer survey method consists simply of a questionnaire seeking individual employers' estimates of the number of persons they will need in various occupational categories at a specified time in the near future - usually 12 to 36 months hence. ${ }^{11}$ Responses are aggregated to determine the global manpower needs. The ratio or trend method has several variants. For some occupations, such as teachers, dentists, physicians, the prevailing or desired ratio of practioners to population is applied to the forecast population and the required manpower in the specific occupation is calculated directly. Alternatively, the ratio may be expressed as the percentage of the total labour force represented by members of the given occupation. This percentage could be held constant or varied in accordance with value judgements about the appropriate level of service that should be provided to the population. A variation of this method is a simple extrapolation of trends in the composition, or occupational mix of the labour force.

The use of econometic models is a somewhat more sophisticated method: the manpower needs are estimated by specifying the detailed labour requirements for producing the forecast output of final goods and services. Such models can range from the very simple statement of a labour/output ratio to a complex computerized model allowing for variations in technology resulting from changes in relative factor prices and improved productivity. 
Forecasts of labour supply are derived from basically one technique. This begins with the number of persons currently in the labour force in a specific occupation; this number is then adjusted by estimating the increases and decreases that will occur over the time period in question. Estimates of graduates from specific educational programs (such as law, medicine, engineering, etc.) will depend on estimates of the population (particularly in the appropriate age group) and the percentage of this population enrolling in and completing the program. This number will be further adjusted according to the expected labour force participation rate for graduates of a specific program, and the percentage of these who will enter the given occupation. One must also take account of previous graduates who will enter or re-enter the labour force after some absence, and the number of persons who will be added through immigration and transfers from other occupations where this is possible. There will also be attrition due to death, retirement, transfer to other occupations, withdrawal from the labour force, and emigration. In short, there are several important and difficult assumptions that must be made in estimating labour supply; when relative salaries, educational financing, and social values are changing rapidly, such estimates can vary widely depending on one's choice of assumptions.

An alternative approach to this matching of supply and demand estimates is to estimate the rate of return to investment in education or training for various occupations. The rationale in making rate-of-return comparisons, as noted previously, is that occupations for which there is a persistently high private rate of return relative to other occupations are deemed to be experiencing a chronic shortage of manpower. This conclusion, however, must be tempered by an examination of the operation of specific labour markets to determine whether adjustments should more appropriately be made on the demand site, ${ }^{12}$ and whether substantial differences in private non-monetary benefits can account for some of the rate-of-return variation. ${ }^{13}$

\section{Some Problems with the Forecasting Methods}

Some of the problems inherent in the rationale and techniques for manpower planning are self-evident. The assumptions of what constitutes an equilibrium wage rate or that public policy should aim for any specific wage rate are assumptions too important to be left to the manpower planners - or to members of specific professions or occupations. In fact, most manpower forecasts have simply tended to ignore wage rates. Second, the time horizon in manpower forecasting is necessarily long; that is, the more expensive the training required, the greater the need for avoiding misallocation of resources, yet expensive programs tend to be long programs and hence to require long horizons or "lead times" in their planning. But longer time horizons open the possibility for greater social and economic change, and hence wider margins of error in planning.

A third general problem area encompasses all the assumptions and data requirements that are entailed in the various techniques that have been described. These include assumptions about the rate and nature of economic expansion in particular regions of the economy, about relative prices and the elasticity of substitution among productive factors, and about personal tastes, social values, and political decisions. Fortunately - at least from the point of view of planning - the basic variables tend to change slowly; the serious difficulty is in forecasting or identifying a change in the direction of the basic forces. A recent example is found in university enrolments: planners had forecast a slowing 
down in the grow th of enrolments in the early 1970 s, but no one anticipated the absolute decline that was experienced in some provinces.

The fourth problem concerns the link between manpower planning and educational planning. Obviously a major determinant of manpower supply is the number of graduates from educational and training programs; hence manpower planning is frequently associated with education planning. This linkage, however, is not an easy one. Questions concerning the destination of graduates have been raised in the context of manpower supply forecasting: What percentage of the graduates will immediately enter the labour force? Into which geographic areas and occupations will they go? The more fundamental question is one of determing the appropriate level and kind of skills or knowledge that are required to enter a specific occupation. The variation in educational preparation for any given occupation is evident in the data drawn from the decennial census. For example, of the 15,075 males who were employed in 1970 as electrical engineers, about 58 percent had a university degree, 11 percent had completed some university, 19 percent had completed Grade 12 or 13 or some non-university further education, 9 percent had attended high school to the end of Grade 9, 10, or 11, and 2 percent had less than Grade 9 schooling.

What is deemed to be an appropriate educational preparation for an occupation is clearly changing over time. One of the most succinct pieces of evidence of this is a paper by David Sewell. ${ }^{14}$ When he examined the education of workers in 232 nonmanagerial occupations in 1961, he found that 28 percent of this group were in occupations where the average educational level was more than one-half school year below the level which employers for those occupations had described as the minimum educational level for new employees. He also found that during the twenty years 1941 to 1961 , about one-half of the increase in the educational level of the Canadian labour force was due to increased educational levels within occupations. This suggests that educational "requirements" are a function of the supply of graduates, rather than the reverse, and/or that the measures of educational achievement (years of schooling) are not consistent over time. In either case, the evidence poses serious problems for a link between educational and manpower planning.

Another problem underlying the methodology of manpower planning is the need to take into account the operation of labour markets. As noted earlier, the market involves not only the demand and supply of one particular occupation but also the interrelationships among various occupations including persons who are outside the labour force. The adjustment mechanism in the market can have a number of possible responses which make forecasting difficult unless all of the possible factors are known.

We will elaborate on this point by indicating the possible factors involved and a specific example of the recent operation of a market. Figure 1 focuses on one occupation but shows the possible reactions of both employers looking for workers and workers looking for jobs. ${ }^{15}$ Each has a number of possible options in addition to a change in the wage rate. They could leave the specific labour market and search elsewhere, they could drop out entirely, or they could change their skill or quality levels. The final result will depend on the alternatives open to each and their relative attractiveness (in monetary and nonmonetary terms). To plan or forecast outcomes perfectly, we therefore have to know not only the demand and supply in a particular occupation but, in fact, all demands and supplies and their relative attractiveness.

Perhaps the most recent dramatic example of the adjustment mechanism of labour 
SIMPLIFIED FLOW DIAGRAM OF AN INDIVIDUAL LABOUR MARKET

SOURCES OF JOB SEEKERS:

UNEMPLOYED - VIA QUIT, LAYOFF, FIRING

- NEU ENTRANT TO LABOUR FORCE

EMPLOYED GUT PREPARED TO DUIT AND CHAMGE JOB

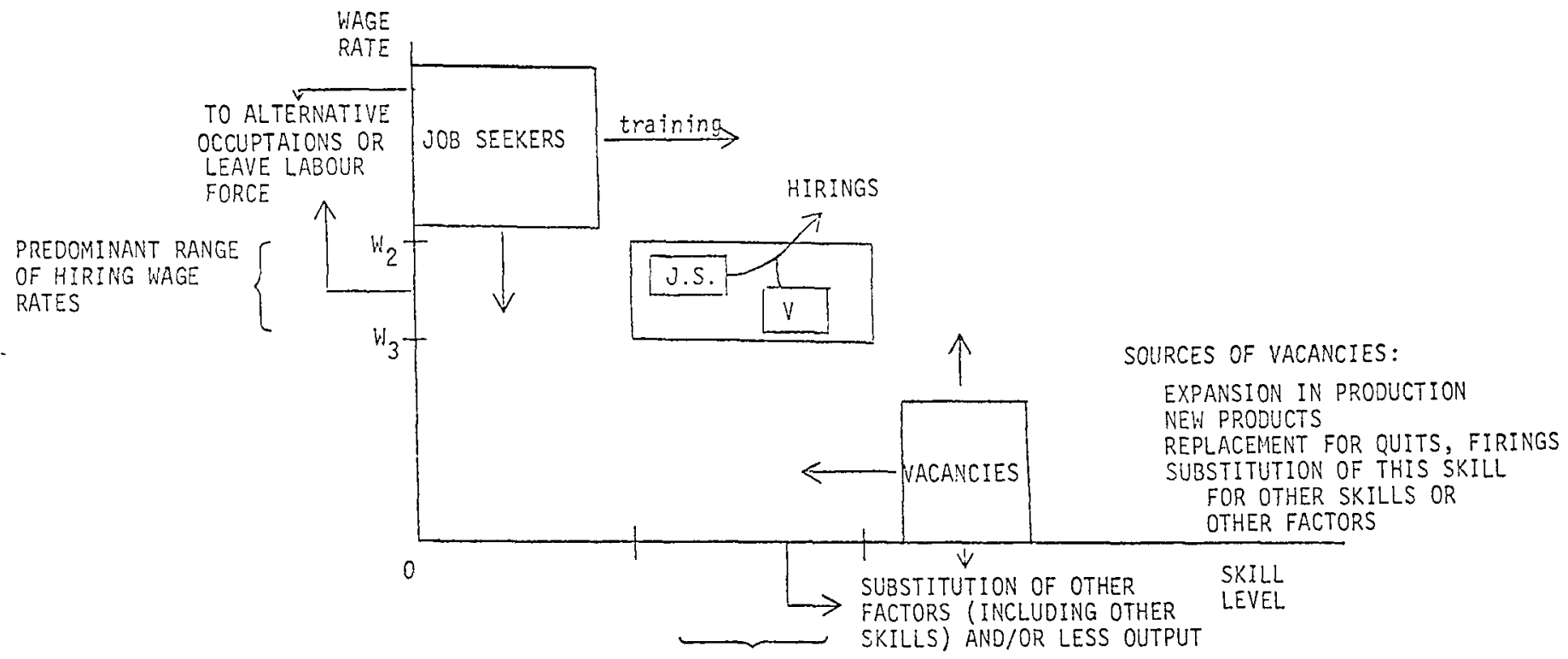

PREDOMINANT RANGE

OF SKILL OF WORKER

BEING HIREO 
markets is that of graduate (or registered) nurses. For Canada as a whole, this occupation showed one of the highest levels and rates of vacancies from 1968 to 1975, ranking in the top five during six of these eight years. ${ }^{16}$ The most recent data, however, indicate that vacancies throughout Canada have been almost eliminated. The Department of Manpower and Immigration's publication Occupational Shortages, Total by Region shows shortages in Canada of 76 persons in August 1976 compared with 722 for August 1975. The Department defines a shortage as a job opening which an employer has been trying to fill continuously for at least thirty days and the net number of vacancies on hand. The figure of 722 in Code 3131130, Nurse, General Duty, was the largest number of long-term vacancies of any seven-digit occupation on the list in August, 1975. The decline in shortages did not occur in Ontario or British Columbia, since by 1975 there were few vacancies. The decline took place in the Atlantic, Quebec and Prairie Regions. ${ }^{17}$ Our suspicion in the absence of more concrete data and analysis is that a major factor contributing to this decline in vacancies was the large increase in salaries which took place for nurses, first in British Columbia in 1974, then in Ontario, and in other provinces subsequently. The Ontario increase was almost 50 percent, bringing beginning general duty nurses to a present (1976) starting salary of $\$ 13,380$ after completion of the two-year community college training program. ${ }^{18}$

The labour market mechanism likely operated as follows. The increase in salaries increased the supply of nurses in several ways. First, the turnover of nurses probably declined as the more attractive salaries induced nurses to remain employed rather than leaving at as rapid a rate as had been the case. In 1966 it was estimated that the annual turnover rate averaged 60 percent. ${ }^{19}$ Second, nurses who had been outside the labour force or in other occupations were likely attracted back into the profession. Third, persons (primarily women), who were considering career choices would now find this occupation relatively more attractive than before, since the rate of return had risen substantially, and would attempt to enrol in the training programs. Since these developments occurred at a time when the demand for teachers was declining, and when training, at least in Ontario, moved from the three-year hospital program to two years in community colleges, the trend to increased applications and enrollments would be accelerated. At the same time the increased salaries would likely have the effect of reducing somewhat the demand for graduate nurses unless governments were prepared to absorb all of the extra salary costs.

Unless manpower planners had been able to anticipate the substantial increase in salaries for nurses, their forecasts would have over-estimated demand and underestimated supply.

Richard Freeman's recent article on the market for new lawyers also indicates the effects of the operation of the market. ${ }^{20} \mathrm{He}$ found that "... the decision to enroll in law school is significantly affected by economic conditions in the profession. . "21 with the salaries of young lawyers being inversely related to numbers of graduates. The result is that ". . the market undergoes highly dempened cobweb-type fluctuations with a peaktrough period of three to four years." 22 He suggests that:

the market for lawyers will likely be depressed in the mid-seventies when the large classes of the late sixties/early seventies graduate. ${ }^{23}$

\section{Experience with Manpower Planning}

Although manpower planning has been widely discussed during the past decade, in fact 
very little manpower planning goes on in Canada. Aside from ad hoc efforts to look at supply and demand in particular sectors, such as the Royal Commission on Health Services, there has been little on-going manpower planning. The Department of Manpower and Immigration has prepared several forecasts of likely demand ${ }^{24}$ but it has not yet included a reconciliation of supply estimates with demand. ${ }^{25}$ The Department's most recent project is the use of the CANDIDE econometric forecasting model to project manpower requirements. The project is termed COFOR (Canadian Occupational Forecasting Program). The data released so far deal with non-professional occupations. The Department also prepares short-term outlooks under the Forward Occupational Imbalances Listing (F.O.I.L.). ${ }^{26}$

Other groups have attempted to include the supply side to a greater extent. Cecily Watson and Joseph Butorac projected manpower stocks in Ontario and then modified ". . the figure in the light of various supply and demand factors." 27 Edward Harvey and K.S.R. Murthy in their recent study have made explicit projections of supply and demand for graduates of engineering, chemistry, business and commerce. ${ }^{28}$ Their projections used the CANDIDE model on the demand side.

There are a number of reasons for the relatively few examples of manpower planning even in the most basic form of supply and demand projections. The first set of reasons is conceptual, namely, the difficulties discussed earlier of selecting the most appropriate format or of attempting to take into consideration the possible interactions in the market.

The second difficulty is empirical. ${ }^{29}$ Aside from the decennial population census, we do not adequately know the current employment situation or unemployment situation for detailed occupations. In reviewing the data on historical trends and projections of the number of lawyers in Ontario, Meltz found confusion among the data bases specifically relating to the actual number of lawyers. ${ }^{30}$ In addition, there were some questions about the reliability of the supply estimates and differences in the demand estimates. When data are finally released from Statistics Canada's Occupational Employment Survey, the first gap will be remedied. The lack of unemployment data may be ended if unemployment insurance data can be related to the more global estimates for occupation groups from the Labour Force Survey. Current vacancy data are, of course, now available through the Job Vacancy Survey. Other data needs which have yet to be met are comprehensive wage and salary figures and information on flows of people into and out of occupations. ${ }^{31}$

Even where projections have been prepared, there is no reason to expect that a unique set of figures will be produced. As with other exercises in "futures", forecasts can differ depending on the underlying assumptions they make and the models used. For example, a recent paper by Betty $M$. Vetter compared the widely different projections of supply and demand for science and engineering doctorates in the United States prepared by the Bureau of Labor Statistics and the National Science Foundation respectively. ${ }^{32}$ She says:

... in the physical sciences, NSF anticipates that $10.5 \%$ of the doctoral workforce will not be able to find science/engineering positions in 1985, while the BLS projection shows an over-supply of $44 \% .^{33}$

If it is so difficult to get some agreement on likely manpower trends, is it possible to consider the more comprehensive notion of manpower planning?

\section{Should There Be Any Manpower Planning at All?}

At the outset, we noted that some persons question the value of attempting any manpower 
planning. Having set out the major conceptual and empirical difficulties in attempting manpower planning, we offer the following observations.

1 There is a role for projections of manpower requirements and supplies as long as the assumptions underlying the projections are made explicit and there is frequent revision in the projections.

2 Manpower projections should be related to analysis of current and recent past developments in the operation of the labour markets for specific occupations. This is particularly important in the professions which, in most cases, require a long lead time for changing domestic supply institutions.

3 Additional data are needed to more effectively undertake current labour market analysis. These data needs have been discussed in depth in the Economic Council of Canada's recent study, People and Jobs.

4 A more comprehensive approach to manpower planning must go beyond simply changing enrollment in educational institutions. The broader examination of labour markets which we have suggested would require consideration of alternatives such as demand-side adjustments, changes in wage and salary rates, changes in immigration policy, etc. ${ }^{34}$

5 Private manpower planning should be encouraged to include labour market operation and projections along with purely personnel matters. Ultimately, firms and government agencies themselves can have an important input into the manpower planning process. 6 As a final point, we suggest that the alternatives should not be thought of as either comprehensive manpower planning or pure laissez faire. As noted earlier, when there are long lead times, the market will tend to produce booms and busts in what economists refer to as a cobweb effect. We suggest a mix of projections and current market analysis, along with the use of a range of policy variables beyond simply altering supply by changing the outputs of the education or immigration systems.

Finally, we come to virtually the same point from which we began, namely, the matter of objectives in manpower planning. The quantity and quality of such planning that occurs in our economy will depend on who provides what answers to the question of objectives.

\section{An earlier version of this paper was presented at a conference on The Professions and} Public Policy, October 15 and 16, 1976, sponsored by the Law and Economics Programme, University of Toronto Faculty of Law. The paper, in the revised form, will appear in a book of essays on the professions which will be published in 1978 by the University of Toronto Press.

\section{Footnotes}

1. See H.S. Parnes "Manpower Analysis in Educational Planning", in H.S. Parnes (ed.), Planning Education for Economic and Social Development, Paris: Organization for Economic Cooperation and Development, 1964, pp. 73-80.

2. See W. Lee Hansen, "Labor Force and Occupational Projections", Industrial Relations Research Association, Proceedings of the 18th. Annual Winter Meetings, New York, December 1965, pp. 10-20 and comments pp. 20-30; and Howard R. Bowen, "The Manpower vs. Free-Choice Principle", in Larry F. Moore, (ed.) Manpower Planning for Canadians: An Anthology, Vancouver: Institute of Industrial Relations, University of British Columbia, 1975, pp. 233-241. 
3. See John W. Holland and Michael L. Skolnik, Public Policy and Manpower Development, Toronto: Ontario Institute for Studies in Education, 1975; and Sar A. Levitan, Garth L. Mangum and Ray Marshall, Human Resources and Labor Markets, second edition, New York: Harper and Row, 1976, chapters 6 and 13.

4. See Noah M. Meltz, "Implications of Manpower and Immigration Policy" in Lawrence Officer and Lawrence Smith (editors), Issues in Canadian Economics, Toronto: McGraw-Hill Ryerson, 1974, pp. 245-257.

5. See Sylvia Ostry and Mahmood Zaidi, Labour Economics in Canada, second edition, Toronto: MacMillan, 1972, pp. 158-181.

6. M.J. Bowman, "Educational Shortage and Excess", Canadian Journal of Economics and Political Science, November 1963, pp. 446-462.

7. Commission on Post-Secondary Education in Ontario, Cost and Benefit Study, Toronto: Queen's Printer, 1972, pp. 93-103.

8. J.R. Walsh, "Capital Concept Applied to Man", Quarterly Journal of Economics, February 1935, pp. 255-85.

9. K.J. Arrow and W.m. Capron, "Dynamic Shortages and Price Rises: The Engineer-Scientist Case", Quarterly Journal of Economics, Vol. 73 (1959), No. 2, pp. 292-308.

10. M. von Zur-Muehlen, "The Ph.D. Dilemma in Canada: A Case Study", in Sylvia Ostry (ed.) Canadian Higher Education in the Seventies, Ottawa: Economic Council of Canada, 1972, pp. 75-131.

11. See Canada Department of Labour, Employment Outlook for Professional Personnel in Scientific and Technical Fields 1962-1964, Professional Manpower Report No. 13, Ottawa: Queen's Printer, December 1962.

12. For example, by improving the productivity of professional manpower providing services directly to the public.

13. See for example, D.A. Dodge and D.A.A. Stager, "Returns to Graduate Study in Science, Engineering and Business", Canadian Journal of Economics, May 1972, pp. 182-198.

14. David Sewell, "Educational Planning Models and the Relationship between Education and Occupation", in Sylvia Ostry (ed.) op. cit., pp. 45-74.

15. This diagram is reproduced from Noah M. Meltz, "Identifying Sources of Imbalance in Individual Labour Markets", Relations Industrielles, Vol. 31, No. 2 (1976), pp. 224-246.

16. Department of Manpower and Immigration, Canada Manpower Review, second quarter, 1974, p. 19; and Statistics Canada, Quarterly Report on Job Vacancies, various issues from second quarter 1974 to first quarter 1976.

17. The vacancies by region for general duty nurses were:

\begin{tabular}{lcccccc} 
& Atlantic & Quebec & Ontario & Prairie & Pacific & Total \\
\hline August 1976 & 6 & 46 & 3 & 10 & 11 & 76 \\
August 1975 & 240 & 189 & 20 & 220 & 49 & 722
\end{tabular}

18. Background information for this section was provided by Ms. Evelyn Wong, Ontario Nurses Association and Mr. Carl Posluns Ontario Hospital Association. We would like to thank them for their assistance. The particular interpretation of the data rests with us.

19. A.G. Atkinson, K.J. Barnes and Ellen Richardson, Canada's Highly Qualified Manpower Resources, Ottawa: Department of Manpower and Immigration, 1970, p. 163.

20. Richard Freeman, "Legal 'Cobwebs': A Recursive Model of the Market for New Lawyers", The Review of Economics and Statistics, Vol. LVII, No. 2, (May 1975), pp. 171-179.

21. Ibid., p. 179 .

22. Ibid.

23 Ibid.

24. See B. Ahamad, A Projection of Manpower Requirements by Occupation in 1975, Ottawa: Department of Manpower and Immigration, 1969; and Noah M. Meltz and G. Peter Penz, Canada's Manpower Requirements in 1970, Ottawa: Queen's Printer, 1968. 
25. For a discussion of the Department's plans, see "Canadian Occupational Forecasting Program", Canada Manpower Review, fourth quarter, 1973, Ottawa: Department of Manpower and Immigration, 1973, pp. 15-17.

26. See FOIL, Forward Occupational Imbalance Listing, Vol. 2, No. 1, April 1976, Ottawa: Department of Manpower and Immigration, 1976.

27. Cecily Watson and Joseph Butorac, Qualified Manpower in Ontario 1961-1986, Toronto: The Ontario Institute for Studies in Education, 1968.

28. Edward Harvey and K.S.R. Murthy, Supply of and Demand for New Graduates in Engineering. Chemistry, Business and Commerce, Toronto: Technical Services Council, 1975.

29. For a recent discussion of labour market information, see Economic Council of Canada, People and Jobs: A Study of the Canadian Labour Market, Ottawa: Information Canada, 1976, chapters 5 and 10.

30. Noah M. Meltz, A Review of Historical Trends and Projections of the Number of Lawyers and Judges in the Ontario Labour Force, prepared for the Committee of Ontario Law Deans, Toronto: Institute for Policy Analysis, University of Toronto, 1974.

31. For a complete discussion of these points, see Economic Council of Canada, op. cit.

32. Betty M. Vetter, "Higher Education in the Changing Employment Market", a paper prepared for the American Council on Education, Fifty-Eighth Annual Meeting, Washington, D.C., October 9, 1975.

33. Ibid., p. 3.

34. See Meltz, "Implications of Manpower and Immigration Policy. .,", loc. cit. 